\title{
Cycloaddition of Azosulfones and Sulfonylimines
}

By Doz. Dr. F. Effenberger and Dipl.-Chem. R. Maier

Institut für Organische Chemie der Technischen Hochschule Stuttgart (Germany)

Ketene N,N-acetals ( 1 ) and ketene $\mathrm{O}, \mathrm{N}$-acetals (2) containing hydrogen in the 2-position afford $\beta$-substitution products when treated with compounds such as isocyanates and isothiocyanates that contain an electrophilic double bond system [1, 2].

However, azosulfones (3) ${ }^{[3]}$ and $N$-sulfonylimines (7) ${ }^{\text {[4] }}$ react with ketene $\mathrm{N}, \mathrm{N}$-acetals (1) by cycloaddition, affording the hitherto unknown 1,2-dihydro-1,2-diazetes (5) (Table 1) and 1,2-dihydroazetes (9) (Table 2), respectively. Ketene $\mathrm{O}, \mathrm{N}$-acetals (2) and azosulfones (3), under comparable conditions, also give 1,2-dihydro-1,2-diazetes (5).

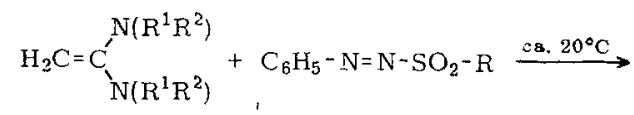

(3)

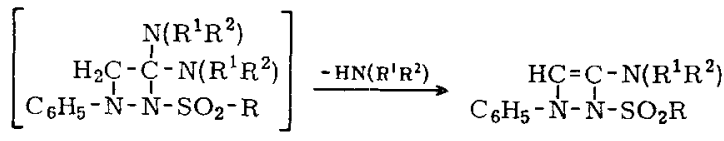

(4)

(5)

$$
\text { ca. } 20^{\circ} \mathrm{C} \uparrow-\text { HOR }^{3}
$$

$H C=C-N\left(R^{1} R^{2}\right)$ $\mathrm{RO}_{2} \mathrm{~S}-\mathrm{N}-\mathrm{N}-\mathrm{C}_{6} \mathrm{H}_{5}$<smiles>[R11]C(=C)NCC</smiles>

(6)

(2)

Table 1, 1,2-Dihydro-1,2-diazedes (5) obtained from ( 1 ) or (2) and (3) in benzene.

\begin{tabular}{|c|c|c|c|c|c|c|c|}
\hline & & & (2) & & (3) & & \\
\hline $\mathbf{R}^{1}$ & $\mathbf{R}^{2}$ & $\mathbf{R}^{1}$ & $\mathrm{R}^{2}$ & $\mathrm{R}^{3}$ & $\mathbf{R}$ & $\begin{array}{l}\text { Yield } \\
{[\%]}\end{array}$ & $\begin{array}{l}\text { M.p. } \\
{\left[{ }^{\circ} \mathrm{C}\right]}\end{array}$ \\
\hline$-(\mathrm{C}$ & & & & & $\mathrm{C}_{6} \mathrm{H}_{5}$ & 50.5 & $148-149$ \\
\hline$-(C)$ & & & & & $p-\mathrm{CH}_{3}-\mathrm{C}_{6} \mathrm{H}_{4}$ & 75.7 & $177-178$ \\
\hline$-(\mathrm{C}$ & & & & & $p-\mathrm{Cl}-\mathrm{C}_{6} \mathrm{H}_{4}$ & 66.8 & $172-173$ \\
\hline $\mathrm{CH}_{3}$ & $\mathrm{CH}_{3}$ & & & & $p-\mathrm{CH}_{3}-\mathrm{C}_{6} \mathrm{H}_{4}$ & 77 & $148-149$ \\
\hline $\mathrm{CH}_{3}$ & $\mathrm{CH}_{3}$ & & & & $p-\mathrm{Cl}-\mathrm{C}_{6} \mathrm{H}_{4}$ & 72.5 & $153-154$ \\
\hline & & $\mathrm{CH}_{3}$ & $\mathrm{CH}_{3}$ & $\mathrm{C}_{2} \mathrm{H}_{5}$ & $\mathrm{C}_{6} \mathrm{H}_{5}$ & 60.2 & $142-144$ \\
\hline & & $\mathrm{CH}_{3}$ & $\mathrm{CH}_{3}$ & $\mathrm{C}_{2} \mathrm{H}_{5}$ & $p-\mathrm{CH}_{3}-\mathrm{C}_{6} \mathrm{H}_{4}$ & 67 & 148 \\
\hline
\end{tabular}

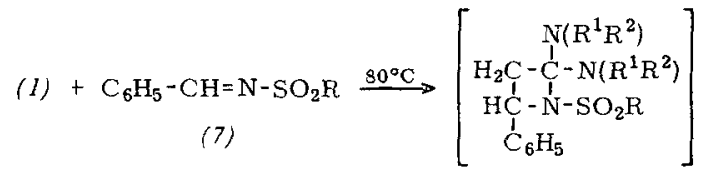

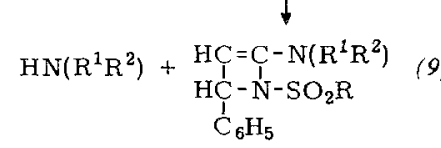

\begin{tabular}{|c|c|c|c|}
\hline \multirow{2}{*}{$\begin{array}{l}(1) \\
\mathrm{R}^{1}+\mathrm{R}^{2}\end{array}$} & \multirow{2}{*}{$\begin{array}{l}\text { (7) } \\
\mathrm{R}\end{array}$} & \multicolumn{2}{|c|}{ (9) } \\
\hline & & $\begin{array}{l}\text { Yield } \\
{[\%]}\end{array}$ & $\begin{array}{l}\text { M.p. } \\
{\left[{ }^{\circ} \mathrm{C}\right]}\end{array}$ \\
\hline$-\left(\mathrm{CH}_{2}\right)_{5}-$ & $\mathrm{C}_{6} \mathrm{H}_{5}$ & 68 & $132-133$ \\
\hline$-\left(\mathrm{CH}_{2}\right)_{5}-$ & $p-\mathrm{CH}_{3}-\mathrm{C}_{6} \mathrm{H}_{4}$ & 60 & $179-181$ \\
\hline$-\left(\mathrm{CH}_{2}\right)_{5}-$ & $p-\mathrm{Cl}-\mathrm{C}_{6} \mathrm{H}_{4}$ & 66.8 & $196-198$ \\
\hline$-\left(\mathrm{CH}_{2}\right)_{2}-\mathrm{O}-\left(\mathrm{CH}_{2}\right)_{2}-$ & $\mathrm{C}_{6} \mathrm{H}_{5}$ & 35 & $146-149$ \\
\hline$-(\mathrm{CH})_{2}-\mathrm{O}-\left(\mathrm{CH}_{2}\right)_{2}-$ & $p-\mathrm{CH}_{3}-\mathrm{C}_{6} \mathrm{H}_{4}$ & 34.3 & 166 \\
\hline
\end{tabular}

Table 2. 1,2-Dihydroazetes (9) from (1) and (7) in benzene at $80^{\circ} \mathrm{C}$. 
Equimolar quantities of the ketene derivative (1) or (2) and the sulfonyl derivative (3) or (7), separately dissolved in anhydrous benzene, are mixed and, depending on the reactivity of the sulfonyl derivative, are kept at room temperature for 2 days or heated under reflux for $2 \mathrm{hr}$. After removal of the benzene by distillation, the products, which mostly separate as oils, crystallize when rubbed with ether or petroleum ether and can be obtained analytically pure by recrystallization from acetonitrile or ethyl acetate. Elemental analysis, molecular weight determinations, as well as infrared and NMR spectra show these to be 1,2-dihydro-1,2-diazetes and -azetes, respectively. The $1: 1$ adducts (4) and (8) that are presumably formed as primary products could not be isolated under the conditions used.

The direction of cycloaddition of the sulfonylimines (7) is proved by NMR investigations (AB spectrum at $\delta \approx 6.7 \mathrm{ppm}$, $\mathrm{J}_{\mathrm{AB}}=17 \mathrm{cps}$ ). However, formation of the isomeric compound (6) in reactions of azosulfones (3) could not be excluded, although we consider formation of compounds (5) more probable because of the electronic influence of the sulfonyl group on the $\mathrm{N}=\mathrm{N}$ double bond.

$\mathrm{N}$-Sulfonylimines (7) react also with 4-(cyclohexen-1-yl)morpholine (10) (molar ratio $1: 1$, in boiling benzene), although the latter is less reactive than compounds (I) and (2); cycloaddition affords compounds (11) (elemental analysis, molecular weight determination, infrared and NMR spectra). Compounds (11) are hydrolysed to ketones (12) in acidic solution.<smiles>C1=C(N2CCOCC2)CCC1</smiles>

(10)

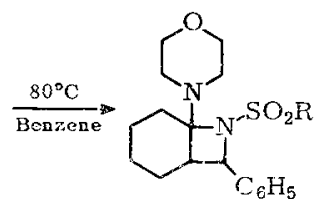

(11)

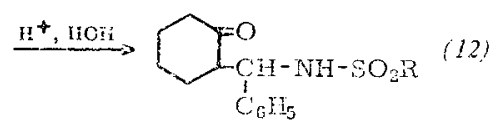

Received: January 27 th, 1966 [Z $153 / 986$ IE German version: Angew. Chem, 78, 389 (1966)

[1] D. H. Clemens, J. A. Bell, and J.L.O'Brien, J. org. Chemistry 29, 2932 (1964)

[2] R. Gleiter, Dissertation, Technische Hochschule Stuttgart 1964; G. Kiefer, Diploma Thesis, Technische Hochschule Stuttgart 1964.

[3] W. Königs, Ber. dtsch. chem. Ges. 10, 1533 (1877).

[4] R. Albrecht, G. Kresze, and B. Mlakar, Chem. Ber. 97, 483 (1964). 